Article

\title{
Cinnamomum cassia and Syzygium aromaticum Essential Oils Reduce the Colonization of Salmonella Typhimurium in an In Vivo Infection Model Using Caenorhabditis elegans
}

\author{
Marie Lang ${ }^{1,2, * \mathbb{C}}$, Aude Montjarret ${ }^{1}$, Emmanuel Duteil ${ }^{1}$ and Gilles Bedoux ${ }^{2} \mathbb{D}$ \\ 1 BioArmor S.A., Z.I de la Gare, F-22940 Plaintel, France; aamata@bioarmor.com (A.M.); \\ eduteil@bioarmor.com (E.D.) \\ 2 Laboratoire de Biotechnologie et Chimie Marines EA 3884, Université Bretagne Sud, F-56100 Lorient, France; \\ gilles.bedoux@univ-ubs.fr \\ * Correspondence: marie.lang@univ-ubs.fr; Tel.: +33-2-97-01-71-22
}

\section{check for} updates

Citation: Lang, M.; Montjarret, A.; Duteil, E.; Bedoux, G. Cinnamomum cassia and Syzygium aromaticum Essential Oils Reduce the Colonization of Salmonella Typhimurium in an In Vivo Infection Model Using Caenorhabditis elegans. Molecules 2021, 26, 5598. https:// doi.org/10.3390/molecules26185598

Academic Editors: Asta Judžentienė and Kristina Ložienè

Received: 16 August 2021

Accepted: 10 September 2021

Published: 15 September 2021

Publisher's Note: MDPI stays neutral with regard to jurisdictional claims in published maps and institutional affiliations.

Copyright: (c) 2021 by the authors. Licensee MDPI, Basel, Switzerland. This article is an open access article distributed under the terms and conditions of the Creative Commons Attribution (CC BY) license (https:// creativecommons.org/licenses/by/ $4.0 /)$.

\begin{abstract}
The regulation of intestinal colonization in livestock by means of non-bactericidal additives is an important management lever for zoonotic bacteria such as Salmonella spp. Caenorhabditis elegans is proposed here as a model for the evaluation of five essential oils (EOs) as anti-colonization products against Salmonella Typhimurium. An evaluation of the toxicity of EOs for C. elegans showed $\mathrm{LD}_{50}$ values ranging from $74.5 \pm 9.6 \mu \mathrm{g} / \mathrm{mL}$ for Cinnamomum cassia (CEO) to $271.6 \pm 14.9 \mu \mathrm{g} / \mathrm{mL}$ for Syzygium aromaticum (SyEO). Both EOs significantly inhibited bacterial colonization in the digestive tract of C. elegans with reductions of 0.88 and $0.70 \log \mathrm{CFU} /$ nematode at nontoxic concentrations of $50 \mu \mathrm{g} / \mathrm{mL}$ and $150 \mu \mathrm{g} / \mathrm{mL}$, respectively. With the minimal bactericidal concentrations of CEO and SyEO against $S$. Typhimurium being $312.5 \mu \mathrm{g} / \mathrm{mL}$ and $625 \mu \mathrm{g} / \mathrm{mL}$, respectively, an antibacterial effect can be excluded to explain the inhibition of the bacterial load. The anti-colonizing activity of these two EOs could, however, be related to an inhibition of the swimming motility, which was significantly reduced by $23.47 \%$ for CEO at $50 \mu \mathrm{g} / \mathrm{mL}$ and $19.56 \%$ for SyEO at $150 \mu \mathrm{g} / \mathrm{mL}$. This study shows the potential of $C$. elegans as a predictive in vivo model of anti-colonizing activities that is suitable for the evaluation of essential oils.
\end{abstract}

Keywords: essential oils; Salmonella Typhimurium; Caenorhabditis elegans; colonization assay; swimming motility; feed additives

\section{Introduction}

Salmonella enterica serovar Typhimurium is an ubiquitous Gram-negative bacteria responsible for zoonoses [1,2]. The presence of Salmonella spp. in poultry, swine, cattle, and other animals involves significant economic losses, but also contamination of the food processing chains. Their ability to develop biofilm structures on many surfaces makes Salmonella spp. particularly persistent, and resistant to antibacterial agents [1,3]. The management of salmonellosis is important in the poultry industry, where the economic impacts are the greatest. Limiting the exposure of animals to the pathogen is a crucial step, and goes through an extensive disinfection of equipment and facilities [4]. Improving their protection by means of vaccines based on dead or attenuated bacteria is also helpful in terms of reducing microbial pressure. The use of pre/probiotics to modulate the microbiota in livestock was also developed to prevent bacterial colonization [4]. The search for anticolonizing additives is, therefore, an interesting axis of research.

Besides their perfume and aroma, essential oils (EOs) develop different biological properties such as antioxidant [5,6], anti-inflammatory [6,7], antiviral [8,9], and antibacterial [10,11]. Activities of EO compounds against the foodborne pathogen Salmonella spp. have already been reported [1]. Carvacrol, cinnamaldehyde and thymol, alone or in combination, show antibacterial activities against $S$. Typhimurium [12] with minimal bactericidal 
concentrations of 200 and $400 \mu \mathrm{g} / \mathrm{mL}$, respectively. Active concentrations were reduced to $100 \mu \mathrm{g} / \mathrm{mL}$ when cinnamaldehyde was combined to carvacrol or thymol [12]. Carvacrol was also successfully used against biofilm of $S$. Typhimurium grown on polystyrene and stainless steel. In these conditions, nonbiocidal concentrations of 60 to $120 \mu \mathrm{g} / \mathrm{mL}$ led to a 2 to 4 -fold reduction in biofilm formation, according to a crystal violet assay [13]. This result showed the relevance of essential oils, alone or in combination, in the management of Salmonella spp. along the food production chain. In vitro measurements generally highlight the biological activities of plant extracts and allow a fast selection of suitable candidates. However, these tests are often mono-parametric or limited to simplified conditions, and biases are observed when switching to complex systems. Due to technical issues, significant costs and ethical reasons, the achievement of large-scale in vivo assays is not possible. The development of intermediate models, allowing a simplified monitoring of the host-pathogen interactions is, therefore, an important issue for the understanding of biological systems.

Caenorhabditis elegans is a small, free-living nematode, isolated from soil and feeding on bacteria. It is currently used as an experimental system for biological studies because of its simplicity, transparency, and ease of cultivation [14]. The nematode is susceptible to various pathogens involved in zoonoses and conserves many biological processes occurring in mammals [15-17]. Colonization of its digestive tract, cuticle or tail as well as other virulence mechanisms will then cause various symptoms, ranging from reduced life expectancy to rapid death [17-19]. These particularities make it an ideal model for the study of hostpathogen interactions [20]. Although, the pathosystem that uses Pseudomonas aeruginosa is today the most widely described [21-23], several studies show that C. elegans can also be an infection model for Salmonella Typhimurium [24]. After ingestion, the bacteria durably colonizes the digestive tract of $C$. elegans and induces an irreversible infection [24]. The persistent infection, linked to an oxidative burst in the digestive tissues, causes lethality within four to seven days [16,25]. Most recently, Desai et al. (2019) [26] showed that Salmonella forms sessile aggregates, comparable to in vivo biofilms, allowing chronical infections of the worm's gut. Indeed, the pathogenicity of bacteria is down-regulated by an inhibition of the SPI-1-encoded tyrosine phosphatase (SptP), inducing an up-regulation of the host innate immunity through the p38-MAPK pathway [26]. The C. elegans/S. Typhimurium pathosystem was previously used to assess the bioactivity of red seaweeds [27]. Antibacterial seaweed water extracts (WE) incorporated in agar media impaired the ability of $S$. Enteritidis to colonize the digestive tract of the nematode and reduced its biofilm formation capacity and motility. The swimming motility in $S$. Typhimurium was recently shown to be related to more productive gut colonization [28]. Worm survival was also significantly improved 13 days after infection (by $65 \%$ for $S$. gaudichaudii WE at $800 \mu \mathrm{g} / \mathrm{mL}$ and by $45 \%$ for C. crispus at $800 \mu \mathrm{g} / \mathrm{mL}$ ) and associated with an over-expression of immunity related genes [27]. An adaptation of the infection model in a liquid system is proposed here for the study of essential oils.

To improve both food and health safety, and the evolution of regulation and antibiotics use, but also to meet consumers' expectations, alternative solutions must be developed. Essential oils are promising ingredients to modulate the colonization of the digestive tract in the management of salmonellosis. Due to their poor solubility in agar media, a microplate-based liquid infection assay, using C. elegans, was developed to evaluate their activities. Colonization of the digestive tract was monitored by isolation and enumeration of the bacterial content. The effects of EOs on S. Typhimurium were then evaluated through antibacterial, antibiofilm and swimming motility inhibition assays.

\section{Results and Discussion}

\subsection{EOs Composition}

The chemical compositions of the essential oils (EOs) are presented in Table 1. Cinnamomum cassia essential oil (CEO) obtained from the leaves contains $79.98 \%$ cinnamaldehyde. Origanum vulgare (OEO) and Satureja hortensis (SaEO) essential oils have the same major 
compound, containing $70.72 \%$ and $47.37 \%$ carvacrol, respectively. Thymus vulgaris (TEO) and Syzygium aromaticum (SyEO) essential oils are also rich in phenolic compounds, with thymol $(40.20 \%)$ and eugenol $(80.67 \%)$, respectively, as the main compounds. The chemical profiles of the essential oils are in accordance with previous data [29-32].

Table 1. Chemical compositions of commercial essential oils (\%) determined by gas chromatography. The compounds are classified according to their concentration in all the tested EOs. These data are provided by the supplier.

\begin{tabular}{|c|c|c|c|c|c|}
\hline & $\begin{array}{c}\text { Cinnamomum } \\
\text { cassia }\end{array}$ & $\begin{array}{c}\text { Origanum } \\
\text { vulgare }\end{array}$ & $\begin{array}{l}\text { Satureja } \\
\text { hortensis }\end{array}$ & $\begin{array}{l}\text { Thymus } \\
\text { vulgaris }\end{array}$ & $\begin{array}{l}\text { Syzygium } \\
\text { aromaticum }\end{array}$ \\
\hline & (CEO) & (OEO) & (SaEO) & (TEO) & (SyEO) \\
\hline Eugenol & & 0.02 & & & 80.67 \\
\hline Cinnamaldehyde (cis + trans) & 79.98 & & & & \\
\hline Carvacrol & & 70.72 & 47.37 & 2.13 & \\
\hline Thymol & & 2.12 & 1.61 & 40.20 & \\
\hline p-Cymene & & 3.70 & 11.59 & 22.04 & \\
\hline$\gamma$-Terpinene & & 4.97 & 27.36 & 11.46 & \\
\hline$\beta$-Caryophyllene & & 3.58 & 1.58 & 3.55 & 9.6 \\
\hline o-Methoxycinnamaldehyde & 8.00 & & & & \\
\hline Eugenyl acetate & & & & & 6.0 \\
\hline Linalool & & 3.00 & 1.04 & 3.66 & \\
\hline Cinnamyl acetate & 2.52 & & & & \\
\hline Myrcene & & & 2.00 & 2.14 & \\
\hline$\alpha$-Terpinene & & 0.58 & 2.09 & 1.80 & \\
\hline Coumarin & 1.56 & & & & \\
\hline D-Limonene & 0.04 & 0.72 & & 0.48 & \\
\hline Eucalyptol & & 1.41 & & & \\
\hline (D,L)-Borneol & & 1.20 & & 1.34 & \\
\hline$\alpha$-Pinene & & & & 1.18 & \\
\hline$\beta$-Pinene & & 1.15 & & & \\
\hline 4-Terpinenol & & & & 1.08 & \\
\hline Benzaldehyde & 0.83 & & & & \\
\hline Camphor & & 0.83 & & & \\
\hline$\alpha$-Terpineol & & 0.76 & & 0.17 & \\
\hline 4-Carvomenthenol & & 0.75 & & & \\
\hline Camphene & & & & 0.70 & \\
\hline Phenylethyl alcohol & 0.70 & & & & \\
\hline trans-Sabinene hydrate & & & & 0.50 & \\
\hline Styrene & 0.21 & & & & \\
\hline Salicylaldehyde & 0.20 & & & & \\
\hline Terpinolene & & & & 0.15 & \\
\hline Cinnamic acid & 0.11 & & & & \\
\hline Cinnamyl alcohol & 0.11 & & & & \\
\hline Benzyl Benzoate & 0.06 & & & & \\
\hline Furfural & & & & & 0.06 \\
\hline
\end{tabular}

\subsection{Assessment of Toxic Concentrations}

The toxicity of EOs was established using a liquid dilution assay on young adult worms. The $\mathrm{LD}_{10}, \mathrm{LD}_{50}$ and $\mathrm{LD}_{90}$ values (doses involving $10 \%, 50 \%$ and $90 \%$ lethality, respectively), reported in Table 2, were deduced from the mortality curves established after $24 \mathrm{~h}$ of contact with the EOs solubilised with Simulsol ${ }^{\circledR}$. While the use of the emulsifier alone did not induce any mortality of nematodes (data not shown), CEO was the most toxic one, with an $\mathrm{LD}_{50}$ of $74.5 \pm 9.6 \mu \mathrm{g} / \mathrm{mL}$. OEO and SaEO presented significantly similar activities whether for $\mathrm{LD}_{50}(113.9 \pm 8.8 \mu \mathrm{g} / \mathrm{mL}$ and $136.9 \pm 20.6 \mu \mathrm{g} / \mathrm{mL}$, respectively) or for $\mathrm{LD}_{90}(263.4 \pm 27.7 \mu \mathrm{g} / \mathrm{mL}$ and $265.7 \pm 33.0 \mu \mathrm{g} / \mathrm{mL}$, respectively). These similarities can be related to the equivalent chemical profiles between the two EOs. TEO showed an $\mathrm{LD}_{50}$ of $186.6 \pm 33.2 \mu \mathrm{g} / \mathrm{mL}$, and SyEO was less toxic, with an $\mathrm{LD}_{50}$ of $271.6 \pm 14.9 \mu \mathrm{g} / \mathrm{mL}$. There are currently no data regarding the toxicity of these EOs on the nematode C. elegans to 
which our results could be compared. However, the $\mathrm{LD}_{50}$ values obtained are in the same concentration ranges as observed with other EOs. Woods et al. (2013) [33] reported an $\mathrm{LD}_{50}$ of $457.0 \mu \mathrm{g} / \mathrm{mL}$ for the EOs of Betula nigra, which was rich in eugenol. In a study comparing the EOs of three Cinnamomum species, Satyal et al. (2013) [34] found out that Cinnamomum glaucescens EO developed high nematicidal activities, with an $\mathrm{LD}_{50}$ of $151.0 \mu \mathrm{g} / \mathrm{mL}$. High toxicity was also observed with the $\mathrm{EO}$ of Murraya paniculata $\left(\mathrm{LD}_{50}=37.0 \mu \mathrm{g} / \mathrm{mL}\right)$ by Dosoky et al. (2016) [35]. The $\mathrm{LD}_{10}$ established by the mathematical model allowed us to determine the maximal non-toxic doses for each essential oil, namely $50 \mu \mathrm{g} / \mathrm{mL}$ for CEO, OEO and SaEO, $100 \mu \mathrm{g} / \mathrm{mL}$ for TEO and $150 \mu \mathrm{g} / \mathrm{mL}$ for SyEO. These concentrations, at which no mortality was noted during the experiments, were used for the infection assay.

Table 2. Evaluation of the toxicity of essential oils on Caenorhabditis elegans and the pathogen Salmonella enterica sv. Typhimurium. Values in $\mu \mathrm{g} / \mathrm{mL}$ are means $\pm \mathrm{SD}(n=6)$. Values with different letters in the same line are significantly different $(p<0.05)$.

\begin{tabular}{|c|c|c|c|c|c|c|}
\hline & & CEO & OEO & SaEO & TEO & SyEO \\
\hline \multirow{3}{*}{ C. elegans } & $\mathrm{LD}_{10}$ & $43.7 \pm 5.4^{\mathrm{a}}$ & $52.8 \pm 4.2^{\mathrm{ab}}$ & $71.6 \pm 18.4^{b c}$ & $91.8 \pm 1.1^{\mathrm{c}}$ & $156.8 \pm 16.0^{\mathrm{d}}$ \\
\hline & $\mathrm{LD}_{50}$ & $74.5 \pm 9.6^{\mathrm{a}}$ & $113.9 \pm 8.8^{b}$ & $136.9 \pm 20.6^{b c}$ & $186.6 \pm 33.2^{c}$ & $271.6 \pm 14.9^{d}$ \\
\hline & $\mathrm{LD}_{90}$ & $127.3 \pm 18.2^{a}$ & $263.4 \pm 27.7^{b}$ & $265.7 \pm 33.0^{b}$ & $305.7 \pm 65.8^{b}$ & $471.2 \pm 3.3^{c}$ \\
\hline \multirow{2}{*}{ S. Typhimurium } & MIC & - & - & - & - & - \\
\hline & $\mathrm{MBC}$ & $312.5 \pm 0.0$ & $312.5 \pm 0.0$ & $312.5 \pm 0.0$ & $312.5 \pm 0.0$ & $625.0 \pm 0.0$ \\
\hline
\end{tabular}

\subsection{Effect of EOs on Bacterial Colonization}

The load of $S$. Typhimurium in the gut of C. elegans was determined after a $24 \mathrm{~h}$ treatment with EOs and expressed as a logCFU/nematode (Figure 1). The effect of EOs was evaluated against gentamicin at $50 \mu \mathrm{g} / \mathrm{mL}$, which was used as a reference antibiotic. Gentamicin induced a reduction in the bacterial load of two log points (5.35 $\pm 0.18 \log \mathrm{CFU} /$ nematode in control condition against $3.31 \pm 0.41 \log \mathrm{CFU} /$ nematode with gentamicin $50 \mu \mathrm{g} / \mathrm{mL}$ ). Only CEO $(50 \mu \mathrm{g} / \mathrm{mL})$ and SyEO $(150 \mu \mathrm{g} / \mathrm{mL})$ showed a significant decrease in the colonization of the digestive tract by $S$. Typhimurium, reducing the bacterial load to $4.47 \pm 0.41 \log \mathrm{CFU} /$ nematode and $4.65 \pm 0.10 \log \mathrm{CFU} /$ nematode, respectively. The anticolonizing effect of these EOs can be linked to the major compounds found in both EOs, namely cinnamaldehyde and eugenol, which represent nearly $80 \%$ of the EOs. If the nematode model has been used previously to identify novel anti-infective agents [20], this is the first time that these EOs are evaluated for their effect against the gut colonization by $S$. Typhimurium. A C. elegans/Pseudomonas aeruginosa model already demonstrated the capacity of SyEO to prevent infection in vivo: at the sub-MIC concentration of $\sim 16 \mathrm{mg} / \mathrm{mL}$, EO enhanced the survival of the worm by $60 \%$ [36]. This study suggested that SyEO interferes with the virulence factors produced by PAO1 and induces cyanide asphyxiation and paralysis [36]. The same research team also reported that menthol (the main compound of peppermint $\mathrm{EO}$ ) was able to modulate the infectivity and virulence of Pseudomonas aeruginosa PAO1 in the C. elegans model at a sub-MIC concentration of $800 \mu \mathrm{g} / \mathrm{mL}$ [37]. In vivo effects were then associated with an inhibition of the biofilm formation and the production of virulence factors by PA01 [37].

For that reason, it is necessary to study the regulation of $S$. Typhimurium intestinal colonization by EOs. The work was continued to find a potential mechanism of action of EOs, considering the order of activity observed for this essay: $\mathrm{CEO}>\mathrm{SyEO}>\mathrm{TEO}>\mathrm{SaEO}>\mathrm{OEO}$. Indeed, EOs are known for their regulatory properties in relation to bacterial growth, biofilm development or bacterial motility [38]. These three parameters play an important role in the virulence and colonization of the digestive tract by Salmonella spp. [39]. 


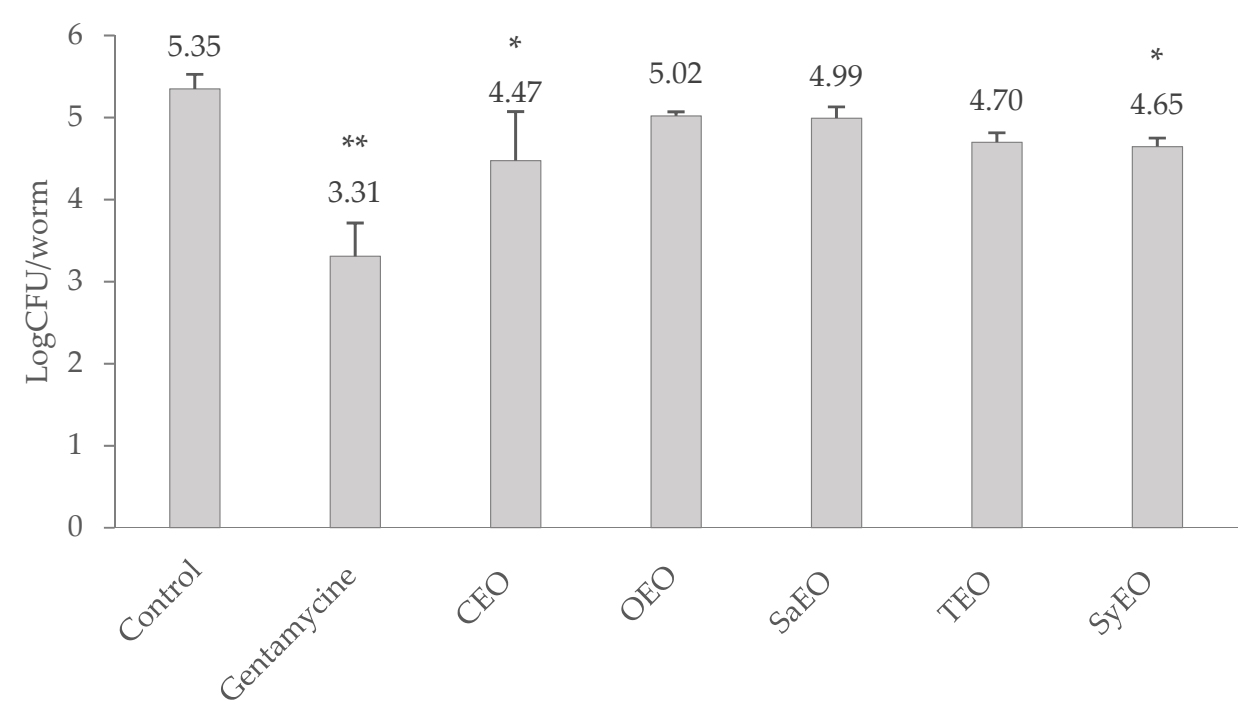

Figure 1. Evaluation of the bacterial load in the digestive tract of Caenorhabditis elegans infected with Salmonella enterica sv Typhimurium, after a $24 \mathrm{~h}$ treatment with essential oils. CEO, OEO and SaEO are tested at $50 \mu \mathrm{g} / \mathrm{mL}, \mathrm{TEO}$ at $100 \mu \mathrm{g} / \mathrm{mL}$, and SyEO at $150 \mu \mathrm{g} / \mathrm{mL}$. Untreated nematodes are used as negative control, and gentamicin at $50 \mu \mathrm{g} / \mathrm{mL}$ is used as positive control. Values in LogCFU/nematode are means $\pm \operatorname{SD}(n=6) .{ }^{*} p<0.05,{ }^{* *} p<0.01$.

\subsection{Antimicrobial Activities of EOs}

An adapted broth microdilution assay was used to determine the minimal inhibitory and bactericidal concentrations of EOs. The values presented in Table 2 show that the CEO, OEO, SaEO and TEO exhibit bactericidal activity from a concentration of $312.5 \mu \mathrm{g} / \mathrm{mL}$. SyEO is less active against $S$. Typhimurium, with an MBC of $625.0 \mu \mathrm{g} / \mathrm{mL}$. As the inhibitory concentrations were very close to the bactericidal concentrations, they could not be determined here. EOs are well known for their antibacterial activities, especially against Salmonella spp., and the activity of their major compounds has also been studied. The main mechanisms of action of carvacrol, eugenol, thymol and cinnamaldehyde were identified by Hyldgaard et al. (2012) [40]. Inhibition of metabolism and ATPase, interactions with lipids from the membrane and, therefore, membrane destabilization, ion losses and dissipation of the $\mathrm{pH}$ gradient, are recurring mechanisms [40]. The values obtained in our work are in the same order of magnitude as previous data. In their study, Si et al. (2006) [41] established an MBC of $300 \mu \mathrm{g} / \mathrm{mL}$ for SyEO and $100 \mu \mathrm{g} / \mathrm{mL}$ for CEO, against the strain of S. typhimurium DT104. These two plant extracts were also evaluated by Oussalah et al., (2007) [42], in addition to SaEO and TEO, against $S$. Typhimurium. They found MICs of $250 \mu \mathrm{g} / \mathrm{mL}$ for CEO, $500 \mu \mathrm{g} / \mathrm{mL}$ for SaEO and $1 \mathrm{mg} / \mathrm{mL}$ for TEO and SyEO. The differences in values can be attributed to the bacterial strain and to the protocol used, since, in the latter, the MICs were determined through an agar dilution assay [42]. It can be noticed that the bactericidal concentrations of the oils are higher than the toxic concentrations on the nematode (Table 2) and, therefore, the working concentrations used in the colonization assay. This allows us to exclude a bactericidal effect of CEO and SyEO in the regulation of the colonization of the digestive tract by $S$. Typhimurium.

\subsection{Effects of EOs on Bacterial Biofilm Formation}

Salmonella spp. are known for their ability to produce biofilm under biotic and abiotic conditions. Sessile aggregates were also observed along the gut of C. elegans, expressing specific genetic markers of biofilm [26]. Biofilm formation seems to be a survival strategy for $S$. Typhimurium, leading to a long-lasting colonization. Anti-biofilm activity could, therefore, be a way by which colonization is inhibited by EOs. To corroborate this mechanism, a liquid broth assay, which was associated with the quantification of biofilm by crystal violet, was realised for the different EOs. The concentrations tested on the 
worms during the colonization assay were used as minimal concentrations here in order to highlight some relations. The results are presented in Figure 2. All the tested EOs exhibited dose-dependent inhibitory activities on the biofilm of $S$. Typhimurium, even where nonbactericidal concentrations were applied (above $300 \mu \mathrm{g} / \mathrm{mL}$ for CEO, OEO, SaEO, and TEO or $600 \mu \mathrm{g} / \mathrm{mL}$ for SyEO) At the concentration of $200 \mu \mathrm{g} / \mathrm{mL}, \mathrm{CEO}$ and OEO $(72.4 \pm 5.7 \%$ and $68.3 \pm 11.9 \%$, respectively) showed significantly higher inhibition rates than SaEO and TEO (33.2 $\pm 9.1 \%$ and $32.4 \pm 10.9 \%$, respectively). This result suggests a better antibiofilm activity of $\mathrm{CEO}$ and $\mathrm{OEO}$ at non-bactericidal concentrations. When bactericidal concentrations were reached $(400 \mu \mathrm{g} / \mathrm{mL})$, only OEO eradicated biofilm formation, with an inhibition of $101.3 \pm 3.2 \%$, suggesting a high correlation between antibacterial and antibiofilm effects. The antibiofilm activity of essential oils was previously established on Salmonella spp. since it is a recurrent pathogen in food processing. Specifically, the activity of TEO and OEO, as well as of the phenolic compound carvacrol, was established on the biofilm of $S$. Typhimurium by Soni et al. (2013) [13]. The monitoring of biomass using a crystal violet assay showed that both EOs significantly reduced the biofilm formation from a concentration of $120 \mu \mathrm{g} / \mathrm{mL}$ [13]. These results are consistent with our observations. At the threshold concentrations, the maximal effect was observed with SaEO $(32.7 \pm 4.0 \%$ inhibition at $50 \mu \mathrm{g} / \mathrm{mL})$, while CEO showed a low and uneven activity $(10.9 \pm 20.2 \%$ at $50 \mu \mathrm{g} / \mathrm{mL}$ ). EOs can be classified again for their antibiofilm activities at the minimal concentration: $\mathrm{SaEO}>\mathrm{TEO}>\mathrm{SyEO}>\mathrm{OEO}>\mathrm{CEO}$. As the order of activity is not preserved when compared to the colonization assay ( $\mathrm{CEO}>\mathrm{SyEO}>\mathrm{TEO}>\mathrm{SaEO}>\mathrm{OEO})$, it seems that the effect of EOs on the bacterial load is not based solely on an antibiofilm activity, although this parameter cannot yet be completely excluded.

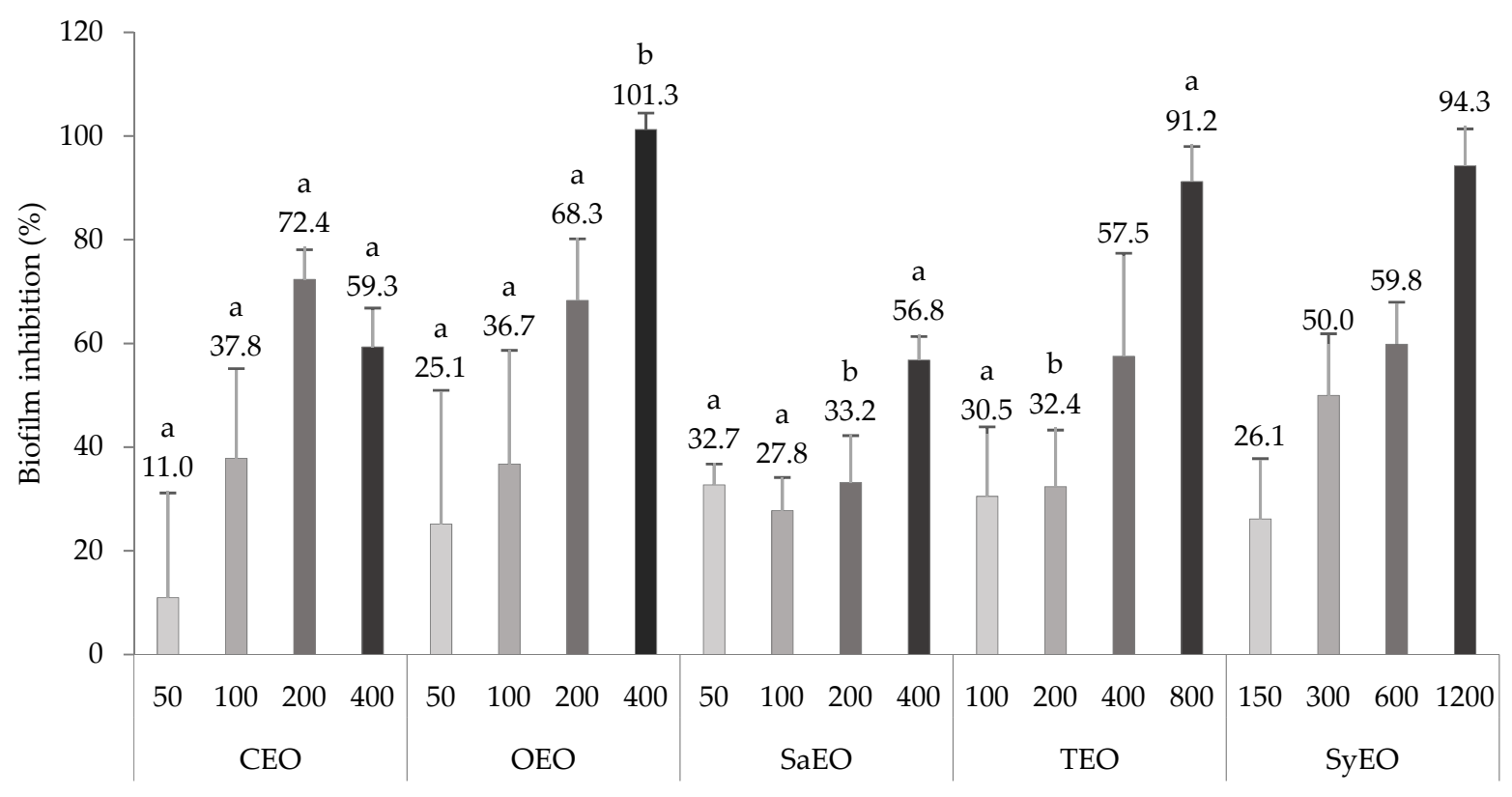

Figure 2. Evaluation of the antibiofilm activity of essential oils on the biofilm of Salmonella sv. Typhimurium formed in microplates. EOs are tested at concentrations greater than or equal to those applied to Caenorhabditis elegans during the colonization assay. Inhibition scores in percentage are means $\pm \mathrm{SD}(n=9)$. EOs at the same concentration with different letters are statistically different $(p<0.05)$.

\subsection{Effects of EOs on Swimming Motility}

Swimming motility can be observed on solid media when low concentrations of agar are used $(<0.25 \%)$. Mediated by flagella, swimming motility initiates cell-to-surface contact [43] and was shown to be a major factor in the ability of Salmonella spp. to colonize digestive tracts $[28,39]$. Bacterial swimming was evaluated by measuring the diameters 
of migration after an incubation with EOs at the concentrations previously tested on the worm model (Figure S1). All of the EOs that were integrated into the growth medium, except OEO, significantly inhibited the motility of $S$. Typhimurium (Figure 3 ). The best effect was obtained with CEO $(50 \mu \mathrm{g} / \mathrm{mL} ; \varnothing 5.9 \pm 0.2 \mathrm{~cm})$, followed by SyEO $(150 \mu \mathrm{g} / \mathrm{mL}$; $\varnothing 6.1 \pm 0.3 \mathrm{~cm}), \mathrm{TEO}(100 \mu \mathrm{g} / \mathrm{mL} ; \varnothing 6.2 \pm 0.4 \mathrm{~cm})$ and $\mathrm{SaEO}(50 \mu \mathrm{g} / \mathrm{mL} ; \varnothing 6.3 \pm 0.4 \mathrm{~cm})$ The conservation of the order of activity between motility and bacterial colonization assays in the worm model $(\mathrm{CEO}>\mathrm{SyEO}>\mathrm{TEO}>\mathrm{SaEO}>\mathrm{OEO}$ ) suggests that the inhibition of swimming motility is a key factor in the regulation of gut colonization by the EOs tested in this study. To our knowledge, this is the first time that the effect of these five EOs on the motility of $S$. Typhimurium was established. However, cinnamaldehyde demonstrated activities on E. coli, which is also responsible of gut colonization [43]. When tested by Niu and Gilbert (2004) [43], cinnamaldehyde, at $286 \mathrm{ng} / \mathrm{mL}$, reduced the swimming motility of E. coli ATCC 33456 by $60 \% \pm 8 \%$ compared to controls. Another work showed a correlation between the inhibition of the cell invasion capacity of Salmonella Enteritidis, and the downregulation of the genes flhC and motA, after a treatment with trans-cinnamaldehyde or eugenol [44]. As a transcriptional factor that leads to the activation of downstream motility genes, flhC also regulates the production of flagellin. The expression of the gene motA regulates flagellar assembly [44]. According to our results, we can suggest that sub-MIC concentrations of $\mathrm{CEO}$ and SyEO affect the expression of flhC and/or motA, leading to defective flagella and impairing the capacity of $S$. Typhimurium to invade the digestive tract of C. elegans.

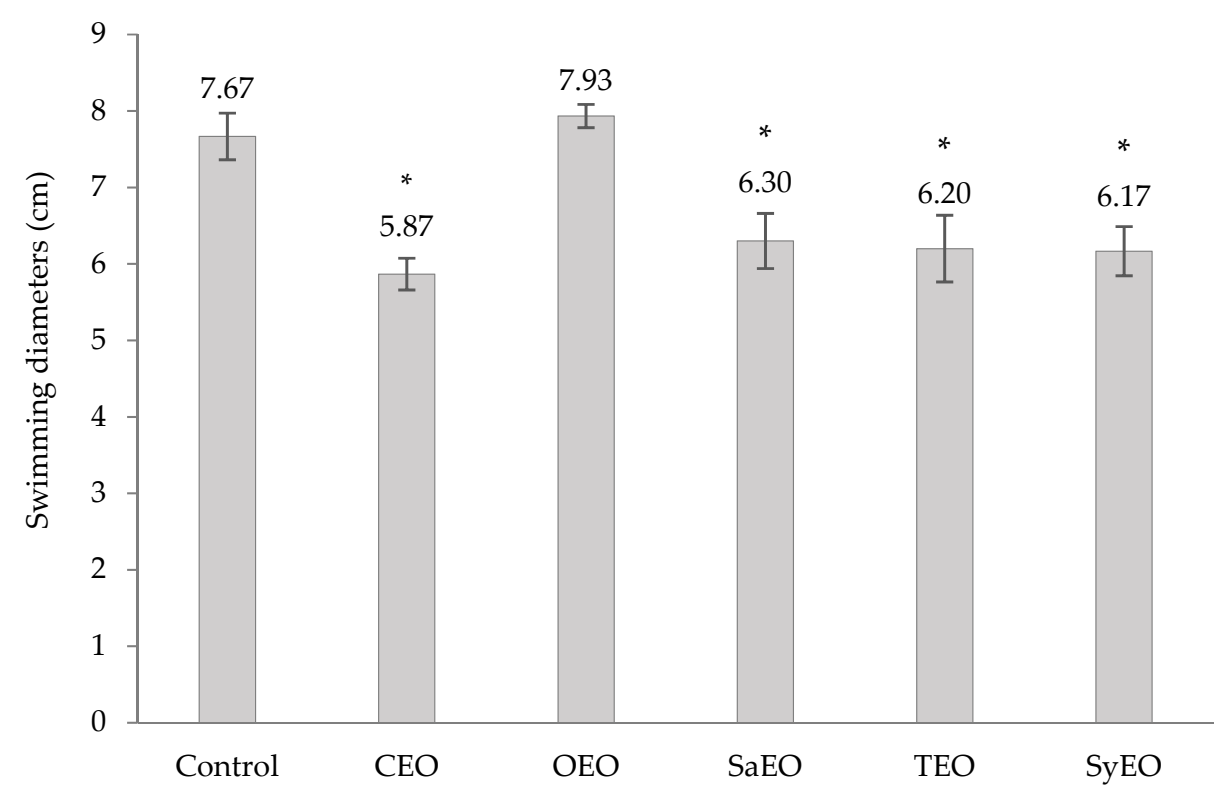

Figure 3. Effect of EOs on the swimming motility of Salmonella sv. Typhimurium. EOs are tested at concentrations equivalent to those applied to Caenorhabditis elegans during the colonization assay, i.e., $50 \mu \mathrm{g} / \mathrm{mL}$ for CEO, OEO and SaEO, $100 \mu \mathrm{g} / \mathrm{mL}$ for TEO, and $150 \mu \mathrm{g} / \mathrm{mL}$ for SyEO. Ethanol, applied at a final concentration of $1 \%$, was used as control. Swimming diameters $(\mathrm{cm})$ are means $\pm \operatorname{SD}(n=3) .{ }^{*} p<0.001$.

\section{Materials and Methods}

\subsection{Essential Oils}

Five essential oils (EOs) obtained from BioArmor S.A. (Plaintel, France) were used in this study. Cinnamomum cassia (CEO), Origanum vulgare (OEO), Satureja hortensis (SaEO), Thymus vulgaris (TEO) and Syzygium aromaticum (SyEO) EOs were extracted by hydrodistillation. Table 1 lists the major components (concentrations $\geq 2 \%$ ) of EOs obtained by gas chromatography, performed by the supplier. Simulsol ${ }^{\circledR}$ (Seppic, Courbevoie, France) an ethoxylated castor oil-based emulsifier, was used to disperse EOs in the different media. Stock solutions were prepared freshly, by mixing equivalent amounts of EOs and 
Simulsol ${ }^{\circledR}$, in the appropriate media. The emulsions were prepared by stirring combined withtwo successive ultrasonic treatments of $4 \mathrm{~min}$. The negative control consisted of diluted Simulsol ${ }^{\circledR}$.

\subsection{Bacterial Strains and Maintenance}

Escherichia coli strain OP50 (Caenorhabditis Genetics Center (CGC)) and Salmonella enterica serovar Typhimurium were used in the different assays. $S$. Typhimurium was isolated from a rag taken from a pig farm and was kindly provided by Labocea (Ploufragan, France). Strains were grown overnight in Luria-Bertani (LB) broth at $37^{\circ} \mathrm{C}$, under orbital agitation (110 rpm).

\subsection{Caenorhabditis Elegans Strain and Maintenance}

Caenorhabditis elegans strain SS104 glp-4(bn2ts) was provided by the CGC, which is funded by the NIH Office of Research Infrastructure Programs (P40 OD010440). This temperature sensitive mutant was used to have a constant number of worms along the colonization assay as it produces progeny at $15{ }^{\circ} \mathrm{C}$ but not at $25{ }^{\circ} \mathrm{C}$. Maintenance and synchronisation methods were adapted from Porta-de-la-Riva et al. (2012) [45].

Nematodes were maintained at $16{ }^{\circ} \mathrm{C}$ on Nematode Growth Medium (NGM) seeded with E. coli OP50. Synchronisation was realised when enough gravid nematodes or eggs were present on the plates. Eggs were recovered by bleaching. The bleaching solution consisted of water, $5 \%$ hypochlorite sodium solution in water and $5 \mathrm{M} \mathrm{KOH}$ buffer in 2:2:1 proportion, according to conventional procedures [45]. The purified eggs were then incubated at $16^{\circ} \mathrm{C}$ under agitation in sterile M9 buffer, until hatching. The L1 larvae thus obtained were rinsed and placed on a layer of E. coli OP50, then incubated at $25^{\circ} \mathrm{C}$ until the young adult (YA) stage was reached (3-4 days).

\subsection{Evaluation of Toxic Concentrations}

The lethal doses (LD) of each essential oil were determined prior to the colonization assay, using a liquid media dilution assay. Approximately 20 Young Adult (YA) nematodes were exposed to serial dilutions of essential oil in S-Basal media. After a 24-h exposure at $25^{\circ} \mathrm{C}$, the mortality rate was determined by counting, using optical microscopy. Nematodes were considered as dead in the absence of movement and pharyngeal pumping. $\mathrm{LD}_{10}, \mathrm{LD}_{50}$ and $\mathrm{LD}_{90}$ values, corresponding to the doses involving $10 \%, 50 \%$ and $90 \%$ death rates, respectively, were determined using the dose effect tool in XLSTAT 2020. Six independent replicates were performed $(n=6)$. This step was intended to determine the working concentrations of the different EOs by selecting the maximum concentrations that induced toxicity of less than or equal to $10 \%$. These concentrations are $50 \mu \mathrm{g} / \mathrm{mL}$ for CEO, $\mathrm{OEO}$ and SaEO, $100 \mu \mathrm{g} / \mathrm{mL}$ for TEO and $150 \mu \mathrm{g} / \mathrm{mL}$ for SyEO.

\subsection{Colonization Assay}

The screening of anti-infective activities against $S$. Typhimurium was performed in liquid medium in 96-well plates. A description of the complete procedure is given in Supplementary Figure S2. For the infection step, YA nematodes, previously washed thrice in M9 buffer to remove OP50, were spotted on a lawn of $S$. Typhimurium grown on Slow Killing (SK) agar plates for $6 \mathrm{~h}$. The infected nematodes were then recovered and washed thrice with M9 buffer and about 10 worms/well were subjected to the different conditions. EOs, as well as gentamicin at $50 \mu \mathrm{g} / \mathrm{mL}$, were diluted in Liquid Kill (LK) media (2/3 SK broth and 1/3 S-Basal buffer) and used for the treatment. LK media with Simulsol ${ }^{\circledR}$ was used as control. Culture media and buffers were prepared as described by Conery et al. (2014) [46].

The enumeration of bacterial Colony Forming Units (CFU) within the gut of C. elegans was performed according to the method presented by Konga et al. (2014) [47] with some modifications. After a 24-h exposure to EOs or antibiotic in liquid medium, approximately 10 living worms were briefly anesthetized in $25 \mathrm{mM}$ Levamisole (Lev). The worms were washed at least thrice in $200 \mu \mathrm{L}$ antibiotic cocktail comprising $25 \mathrm{mM}$ Lev and gentamicin 
at $10 \mu \mathrm{g} / \mathrm{mL}$ for an overall time of $45 \mathrm{~min}$ (15 min/ step) to completely kill the bacterial cells that were associated with the worm cuticle. Then, the worms were washed thrice with $200 \mu \mathrm{L}$ of $25 \mathrm{mM}$ Lev to eliminate the killed bacteria and residual antibiotic. The numbers of worms were recorded before mechanical disruption in $50 \mu \mathrm{L}$ of $1 \%$ Triton $X$ (X100; Sigma-Aldrich, Saint-Louis, MO, USA), using a pestle. Serial dilutions of the worm lysates were performed and $100 \mu \mathrm{L}$ of each dilution were spotted on LB agar. Colonies were counted after an overnight incubation of the plates at $37^{\circ} \mathrm{C}$. The bacterial CFU per worm was calculated using the formula reported by Ooi et al. (2012) [19]. Six independent replicates were performed $(n=6)$.

\subsection{MIC and MBC Determination}

The minimum inhibitory (MIC) and bactericidal (MBC) concentrations were determined for each EO on Salmonella Typhimurium using a broth microdilution assay. The emulsion of essential oils in water-based media implied the appearance of a cloudiness; MTT was used to reveal the presence of metabolically active bacteria. EOs were diluted in LB medium within a range of 5 to $0.05 \mathrm{mg} / \mathrm{mL}$. A volume of $195 \mu \mathrm{L}$ of each dilution was placed in the wells of a flat bottomed 96-well microplate and bacterial suspension was added to obtain a final Optical Density (OD) of 0.0125 at $600 \mathrm{~nm}$ (Shimadzu UV-1800 spectrophotometer Shimadzu Europa GmBh, Duisburg, Germany). Microplates were incubated for $24 \mathrm{~h}$ at $37^{\circ} \mathrm{C}$ without agitation. After cell growth, a tetrazolium salt (MTT, SigmaAldrich, Saint-Louis, USA) solution in DMSO (Fisher Scientific, Hampton, NY, USA) was added to each well at a final concentration of $90 \mu \mathrm{g} / \mathrm{mL}$ and plates were incubated for $30 \mathrm{~min}$. This allowed viable microorganisms to metabolize the yellow MTT into purple formazan crystals. An aliquot of each well that did not present a formazan production was then spread on LB agar plates and incubated for $24 \mathrm{~h}$ at $37^{\circ} \mathrm{C}$ for the determination of MIC or MBC. The MIC and MBC corresponded to the lower concentrations that led to growth or the absence of growth, respectively, after spreading. Six independent replicates were performed $(n=6)$.

\subsection{Inhibition of Biofilm Formation}

The antibiofilm properties of essential oils on Salmonella Typhimurium were evaluated using a microtiter plate assay adapted from Kalai Chelvam et al. (2014) [39]. Briefly, an overnight culture of $S$. Typhimurium was subcultured in LB to a concentration of 0.1 $\mathrm{OD}_{600 \mathrm{~nm}}$ and $100 \mu \mathrm{L}$ of this solution was inoculated in the wells of a microtiter plate. Quantities of $100 \mu \mathrm{L}$ of the EOs' solutions were then added to reach final concentration ranging from 50 to $400 \mu \mathrm{g} / \mathrm{mL}$ for CEO, OEO and SaEO, from 100 to $800 \mu \mathrm{g} / \mathrm{mL}$ for TEO, and from 150 to $1200 \mu \mathrm{g} / \mathrm{mL}$ for SyEO. To evaluate the potential activity of Simulsol ${ }^{\circledR}$ on biofilm formation, dilutions of the emulsifier in the adequate range of concentrations ( 50 to $400 \mu \mathrm{g} / \mathrm{mL}, 100$ to $800 \mu \mathrm{g} / \mathrm{mL}$, or 150 to $1200 \mu \mathrm{g} / \mathrm{mL}$ ) were used as blanks. Wells with LB alone or LB inoculated with $S$. Typhimurium were used as positive and negative controls, respectively.

After a $48 \mathrm{~h}$ period of incubation at $37^{\circ} \mathrm{C}$, unbound cells were removed by inversion of microtiter plate, followed by vigorous tapping on absorbent paper. Subsequently, adhered cells were heat fixed in an oven for $1 \mathrm{~h}$ at $80^{\circ} \mathrm{C}$. Adhered cells were stained by addition of $200 \mu \mathrm{L}$ of crystal violet $(0.5 \%$ in water) for $15 \mathrm{~min}$. The stain was removed by thorough washing with distilled water. To quantify the adhered cells, $200 \mu \mathrm{L}$ of decolouring solution (ethanol/acetone, 80:20\%) was added to each well for $15 \mathrm{~min}$. The absorption of the released stain was measured at $600 \mathrm{~nm}$ wavelength. Based on the OD at $600 \mathrm{~nm}$, inhibition (in \%) was calculated from the absorbance. Nine independent replicates were performed $(n=9)$.

\subsection{Swimming Motility Assay}

To evaluate the effect of EOs on bacterial motility, a swimming assay was carried out on agar plate, as previously described [39]. Swim plates were prepared freshly, with LB supplemented with $0.5 \%$ glucose and $0.25 \%$ agar. Media was complemented after sterilisation 
with EOs at final concentrations of $50 \mu \mathrm{g} / \mathrm{mL}$ (CEO, OEO and SaEO), $100 \mu \mathrm{g} / \mathrm{mL}$ (TEO) or $150 \mu \mathrm{g} / \mathrm{mL}$ (SyEO) that were previously solubilised in absolute ethanol (final concentration of $1 \%$ ). Swim media complemented with ethanol at $1 \%$ was used as negative control. Swim plates were dried for $2 \mathrm{~h}$ under laminar flow before inoculation with $S$. Typhimurium that was previously diluted to a concentration of $0.1 \mathrm{OD}$ at $600 \mathrm{~nm}$. Plates were then incubated for $14 \mathrm{~h}$ at $30{ }^{\circ} \mathrm{C}$ in a humid atmosphere. Swimming diameters were measured (in $\mathrm{cm}$ ) and images were taken using a GeneFlash system (Syngene, India). Three independent replicates were performed $(n=3)$.

\subsection{Statistical Analysis}

Conventional statistical methods were used to calculate means and standard deviations. For the colonization and antibiofilm assays and for the evaluation of swimming motility, an analysis of variance (ANOVA) was performed to determine differences $(p<0.05)$, and means were compared to the control condition using Dunnett's test in combination with Tukey's test. The statistical analyses were realised using XLSTAT 2020 for Windows.

\section{Conclusions}

This work contributes to the development of an in vivo model that is suitable for the study of essential oils' effects on the gut colonization by Salmonella Typhimurium. The results showed that the EOs of Cinnamomum cassia and Syzygium aromaticum, at non-toxic and non-bactericidal doses, regulate the development of $S$. Typhimurium in the digestive tract of $C$. elegans. This result should allow the development of solutions intended to reduce the occurrence of Salmonella spp. in production animals, thereby avoiding contamination of the food chain. While EOs limit both the biofilm formation and motility of $S$. Typhimurium, the observed anti-colonizing effect was mainly related to an inhibition of swimming motility. A defect in swimming motility, regulated by the movement of flagella, is linked to lower adhesion capacity in epithelial cells [28]. According to the literature, the most likely mechanism of action for CEO and SyEO remains an inhibition of the expression of the motility-specific genes flhC and motA [44]. This proposition must, however, be confirmed by more in-depth studies. Previous publications showed that $S$. typhimurium is able to regulate the immune system of $C$. elegans to promote its infection [26], and that its installation in the digestive system is combined with oxidative stress [25]. As both immunomodulative [48] and antioxidant activities of EOs are recognized, further work should also focus on the development of a multiparametric assay that integrates the measurement of oxidative bursts related to infection in C. elegans.

Supplementary Materials: The following are available online. Figure S1: Pictures of swimming motility plates inoculated with Salmonella sv. Typhimurium; Figure S2: Workflow of in vivo colonization assay.

Author Contributions: Conceptualization, M.L., A.M., E.D. and G.B.; methodology, M.L. and G.B.; validation, M.L., E.D. and G.B.; formal analysis, M.L.; investigation, M.L.; resources, M.L., A.M., E.D. and G.B.; data curation, M.L., E.D. and G.B.; writing-original draft preparation, M.L.; writingreview and editing, M.L., A.M., E.D. and G.B.; visualization, M.L.; supervision, E.D. and G.B.; project administration, E.D. and G.B.; All authors have read and agreed to the published version of the manuscript.

Funding: This research was funded by Région Bretagne, grant number 18004512.

Institutional Review Board Statement: Not applicable.

Informed Consent Statement: Not applicable.

Acknowledgments: The authors want to thank Nolwenn Terme for her helpful comments on this work.

Conflicts of Interest: The authors declare no conflict of interest. In addition, the funders had no role in the design of the study; in the collection, analyses, or interpretation of data; in the writing of the manuscript, or in the decision to publish the results. 


\section{References}

1. Bajpai, V.K.; Baek, K.H.; Kang, S.C. Control of Salmonella in foods by using essential oils: A review. Food Res. Int. 2012, 45, 722-734. [CrossRef]

2. Merino, L.; Procura, F.; Trejo, F.M.; Bueno, D.J.; Golowczyc, M.A. Biofilm formation by Salmonella sp. in the poultry industry: Detection, control and eradication strategies. Food Res. Int. 2019, 119, 530-540. [CrossRef] [PubMed]

3. Piovezan, M.; Sayuri Uchida, N.; Fiori da Silva, A.; Grespan, R.; Regina Santos, P.; Leite Silva, E.; Kenji Nakamura Cuman, R.; Machinski Junior, M.; Martha Graton Mikcha, J. Effect of cinnamon essential oil and cinnamaldehyde on Salmonella Saintpaul biofilm on a stainless steel surface. J. Gen. Appl. Microbiol. 2014, 60, 119-121. [CrossRef]

4. Trampel, D.W.; Holder, T.G.; Gast, R.K. Integrated farm management to prevent Salmonella Enteritidis contamination of eggs. J. Appl. Poult. Res. 2014, 23, 353-365. [CrossRef]

5. Hussain, A.I.; Anwar, F.; Shahid, M.; Ashraf, M.; Przybylski, R. Chemical composition, and antioxidant and antimicrobial activities of essential oil of spearmint (Mentha spicata L.) from pakistan. J. Essent. Oil Res. 2010, 22, 78-84. [CrossRef]

6. Miguel, M.G. Antioxidant and anti-inflammatory activities of essential oils: A short review. Molecules 2010, 15, 9252-9287. [CrossRef] [PubMed]

7. De Cássia Da Silveira E Sá, R.; Andrade, L.N.; De Sousa, D.P. A review on anti-inflammatory activity of monoterpenes. Molecules 2013, 18, 1227-1254. [CrossRef] [PubMed]

8. Astani, A.; Reichling, J.; Schnitzler, P. Screening for antiviral activities of isolated compounds from essential oils. Evidence-based Complement. Altern. Med. 2011, 2011. [CrossRef] [PubMed]

9. Pilau, M.R.; Alves, S.H.; Weiblen, R.; Arenhart, S.; Cueto, A.P.; Lovato, L.T. Antiviral activity of the Lippia graveolens (Mexican oregano) essential oil and its main compound carvacrol against human and animal viruses. Braz. J. Microbiol. 2011, 42, $1616-1624$. [CrossRef]

10. Du, E.; Gan, L.; Li, Z.; Wang, W.; Liu, D.; Guo, Y. In vitro antibacterial activity of thymol and carvacrol and their effects on broiler chickens challenged with Clostridium perfringens. J. Anim. Sci. Biotechnol. 2015, 6, 58. [CrossRef]

11. Ballester-Costa, C.; Sendra, E.; Fernández-López, J.; Pérez-Álvarez, J.A.; Viuda-Martos, M. Chemical composition and in vitro antibacterial properties of essential oils of four Thymus species from organic growth. Ind. Crop. Prod. 2013, 50, 304-311. [CrossRef]

12. Zhou, F.; Ji, B.; Zhang, H.; Jiang, H.; Yang, Z.; Li, J.; Li, J.; Yan, W. The antibacterial effect of cinnamaldehyde, thymol, carvacrol and their combinations against the foodborne pathogen Salmonella typhimurium. J. Food Saf. 2007, 27, 124-133. [CrossRef]

13. Soni, K.A.; Oladunjoye, A.; Nannapaneni, R.; Schilling, M.W.; Silva, J.L.; Mikel, B.; Bailey, R.H. Inhibition and inactivation of Salmonella typhimurium biofilms from polystyrene and stainless steel surfaces by essential oils and phenolic constituent carvacrol. J. Food Prot. 2013, 76, 205-212. [CrossRef]

14. Ikeda, T.; Yasui, C.; Hoshino, K.; Arikawa, K.; Nishikawa, Y. Influence of lactic acid bacteria on longevity of Caenorhabditis elegans and host defense against Salmonella enterica serovar Enteritidis. Appl. Environ. Microbiol. 2007, 73, 6404-6409. [CrossRef]

15. Moy, T.I.; Ball, A.R.; Anklesaria, Z.; Casadei, G.; Lewis, K.; Ausubel, F.M. Identification of novel antimicrobials using a live-animal infection model. Proc. Natl. Acad. Sci. USA 2006, 103, 10414-10419. [CrossRef]

16. Sifri, C.D.; Begun, J.; Ausubel, F.M. The worm has turned-Microbial virulence modeled in Caenorhabditis elegans. Trends Microbiol. 2005, 13, 119-127. [CrossRef]

17. Powell, J.R.; Ausubel, F.M. Models of Caenorhabditis elegans infection by bacterial and fungal pathogens. Methods Mol. Biol. 2008, 415, 403-427. [CrossRef] [PubMed]

18. Ganesh, P.S.; Rai, R.V. Inhibition of quorum-sensing-controlled virulence factors of Pseudomonas aeruginosa by Murraya koenigii essential oil: A study in a Caenorhabditis elegans infectious model. J. Med. Microbiol. 2016, 65, 1528-1535. [CrossRef]

19. Ooi, S.K.; Lim, T.Y.; Lee, S.H.; Nathan, S. Burkholderia pseudomallei kills Caenorhabditis elegans through virulence mechanisms distinct from intestinal lumen colonization. Virulence 2012, 3, 485-496. [CrossRef]

20. Kong, C.; Eng, S.-A.; Lim, M.-P.; Nathan, S. Beyond Traditional Antimicrobials: A Caenorhabditis elegans Model for Discovery of Novel Anti-infectives. Front. Microbiol. 2016, 7, 1956. [CrossRef]

21. Peterson, N.D.; Pukkila-Worley, R. Caenorhabditis elegans in high-throughput screens for anti-infective compounds. Curr. Opin. Immunol. 2018, 54, 59-65. [CrossRef] [PubMed]

22. Anderson, Q.L.; Revtovich, A.V.; Kirienko, N.V. A High-throughput, High-content, Liquid-based C. elegans Pathosystem. J. Vis. Exp. 2018, 2018, 1-12. [CrossRef] [PubMed]

23. Tan, M.W.; Ausubel, F.M. Caenorhabditis elegans: A model genetic host to study Pseudomonas aeruginosa pathogenesis. Curr. Opin. Microbiol. 2000, 3, 29-34. [CrossRef]

24. Labrousse, A.; Chauvet, S.; Couillault, C.; Léopold Kurz, C.; Ewbank, J.J. Caenorhabditis elegans is a model host for Salmonella typhimurium. Curr. Biol. 2000, 10, 1543-1545. [CrossRef]

25. Sem, X.H.; Rhen, M. Pathogenicity of Salmonella enterica in Caenorhabditis elegans Relies on Disseminated Oxidative Stress in the Infected Host. PLoS ONE 2012, 7, 1-14. [CrossRef]

26. Desai, S.K.; Padmanabhan, A.; Harshe, S.; Zaidel-Bar, R.; Kenney, L.J. Salmonella biofilms program innate immunity for persistence in Caenorhabditis elegans. Proc. Natl. Acad. Sci. USA 2019, 116, 12462-12467. [CrossRef]

27. Kulshreshtha, G.; Borza, T.; Rathgeber, B.; Stratton, G.S.; Thomas, N.A.; Critchley, A.; Hafting, J.; Prithiviraj, B. Red Seaweeds Sarcodiotheca gaudichaudii and Chondrus crispus down Regulate Virulence Factors of Salmonella Enteritidis and Induce Immune Responses in Caenorhabditis elegans. Front. Microbiol. 2016, 7, 421. [CrossRef] 
28. Horstmann, J.A.; Zschieschang, E.; Truschel, T.; de Diego, J.; Lunelli, M.; Rohde, M.; May, T.; Strowig, T.; Stradal, T.; Kolbe, M.; et al. Flagellin phase-dependent swimming on epithelial cell surfaces contributes to productive Salmonella gut colonisation. Cell. Microbiol. 2017, 19, e12739. [CrossRef]

29. Ooi, L.S.M.; Li, Y.; Kam, S.-L.; Wang, H.; Wong, E.Y.L.; Ooi, V.E.C. Antimicrobial Activities of Cinnamon Oil and Cinnamaldehyde from the Chinese Medicinal Herb Cinnamomum cassia Blume. Am. J. Chin. Med. 2006, 34, 511-522. [CrossRef]

30. Fratini, F.; Casella, S.; Leonardi, M.; Pisseri, F.; Ebani, V.V.; Pistelli, L.; Pistelli, L. Antibacterial activity of essential oils, their blends and mixtures of their main constituents against some strains supporting livestock mastitis. Fitoterapia 2014, 96, 1-7. [CrossRef]

31. Alinkina, E.S.; Misharina, T.A.; Fatkullina, L.D. Antiradical properties of oregano, thyme, and savory essential oils. Appl. Biochem. Microbiol. 2012, 49, 73-78. [CrossRef]

32. Murbach Teles Andrade, B.F.; Nunes Barbosa, L.; da Silva Probst, I.; Fernandes Júnior, A. Antimicrobial activity of essential oils. J. Essent. Oil Res. 2014, 26, 34-40. [CrossRef]

33. Woods, K.E.; Chhetri, B.K.; Jones, C.D.; Goel, N.; Setzer, W.N. Bioactivities and compositions of Betula nigra essential oils. J. Med. Act. Plants 2013, 2, 1-9. [CrossRef]

34. Satyal, P.; Paudel, P.; Poudel, A.; Dosoky, N.S.; Pokharel, K.K.; Setzer, W.N. Bioactivities and compositional analyses of Cinnamomum essential oils from Nepal: C. camphora, C. tamala, and C. glaucescens. Nat. Prod. Commun. 2013, 8, 1777-1784. [CrossRef] [PubMed]

35. Dosoky, N.; Satyal, P.; Gautam, T.; Setzer, W. Composition and Biological Activities of Murraya paniculata (L.) Jack Essential Oil from Nepal. Medicines 2016, 3, 7. [CrossRef]

36. Husain, F.M.; Ahmad, I.; Asif, M.; Tahseen, Q. Influence of clove oil on certain quorum-sensing-regulated functions and biofilm of Pseudomonas aeruginosa and Aeromonas hydrophila. J. Biosci. 2013, 38, 835-844. [CrossRef] [PubMed]

37. Husain, F.M.; Ahmad, I.; Khan, M.S.; Ahmad, E.; Tahseen, Q.; Khan, M.S.; Alshabib, N.A. Sub-MICs of Mentha piperita essential oil and menthol inhibits AHL mediated quorum sensing and biofilm of Gram-negative bacteria. Front. Microbiol. 2015, 6, 1-12. [CrossRef]

38. Faleiro, M.L. The mode of antibacterial action of essential oils. In Science against Microbial Pathogens: Communicating Current Research and Technological Advances; Mendez-Vilas, A., Ed.; Formatex Research Center: Badajoz, Spain, 2011; Volume 3, pp. 1143-1156, ISBN-13: 978-84-939843-1-1.

39. Kalai Chelvam, K.; Chai, L.C.; Thong, K.L. Variations in motility and biofilm formation of Salmonella enterica serovar Typhi. Gut Pathog. 2014, 6, 1-10. [CrossRef]

40. Hyldgaard, M.; Mygind, T.; Meyer, R.L. Essential Oils in Food Preservation: Mode of Action, Synergies, and Interactions with Food Matrix Components. Front. Microbiol. 2012, 3, 12. [CrossRef]

41. Si, W.; Gong, J.; Tsao, R.; Zhou, T.; Yu, H.; Poppe, C.; Johnson, R.; Du, Z. Antimicrobial activity of essential oils and structurally related synthetic food additives towards selected pathogenic and beneficial gut bacteria. J. Appl. Microbiol. 2006, 100, 296-305. [CrossRef]

42. Oussalah, M.; Caillet, S.; Saucier, L.; Lacroix, M. Inhibitory effects of selected plant essential oils on the growth of four pathogenic bacteria: E. coli O157:H7, Salmonella Typhimurium, Staphylococcus aureus and Listeria monocytogenes. Food Control 2007, 18, 414-420. [CrossRef]

43. Niu, C.; Gilbert, E.S. Colorimetric Method for Identifying Plant Essential Oil Components That Affect Biofilm Formation and Structure. Appl. Environ. Microbiol. 2004, 70, 6951-6956. [CrossRef] [PubMed]

44. Kollanoor-Johny, A.; Mattson, T.; Baskaran, S.A.; Amalaradjou, M.A.; Babapoor, S.; March, B.; Valipe, S.; Darre, M.; Hoagland, T.; Schreiber, D.; et al. Reduction of Salmonella enterica serovar enteritidis colonization in 20-day-old broiler chickens by the plant-derived compounds trans-cinnamaldehyde and eugenol. Appl. Environ. Microbiol. 2012, 78, 2981-2987. [CrossRef] [PubMed]

45. Porta-de-la-Riva, M.; Fontrodona, L.; Villanueva, A.; Cerón, J. Basic Caenorhabditis elegans methods: Synchronization and observation. J. Vis. Exp. 2012, 64, e4019. [CrossRef]

46. Conery, A.L.; Larkins-Ford, J.; Ausubel, F.M.; Kirienko, N.V. High-Throughput Screening for Novel Anti-Infectives Using a C. elegans Pathogenesis Model. Curr. Protoc. Chem. Biol. 2014, 6, 25-37. [CrossRef]

47. Konga, C.; Rahmanb, N.A.; Nathana, S. Identification of potential anti-infectives against staphylococcus aureus using a Caenorhabditis elegans infection model. AIP Conf. Proc. 2014, 1614, 513-516. [CrossRef]

48. Lang, M.; Ferron, P.-J.; Bursztyka, J.; Montjarret, A.; Duteil, E.; Bazire, A.; Bedoux, G. Evaluation of immunomodulatory activities of essential oils by high content analysis. J. Biotechnol. 2019, 303, 65-71. [CrossRef] 